\title{
Analisis Potensi Tanah Longsor Menggunakan Sistem Informasi Geografis dan Analytical Hierarchy Process (AHP) (Studi Kasus: Kecamatan Songgon, Kabupaten Banyuwangi)
}

\author{
Potential Analysis of Landslides Using Geographic Information Systems and Analytical Hierarchy Process (AHP) \\ (Case Study: Songgon District, Banyuwangi Regency)
}

\author{
Permata Prasindya $^{1}$, Teguh Hariyanto*2 ${ }^{2}$ Akbar Kurniawan ${ }^{3}$ \\ ${ }^{1,2,3}$ Departemen Teknik Geomatika, FTSLK-ITS, Kampus ITS Sukolilo, Surabaya, 60111, Indonesia \\ *Korespondensi penulis: tgh_hary@yahoo.com
}

Diterima : 11082020; Diperbaiki : 01092020; Disetujui : 05092020; Dipublikasi : 13112020

\begin{abstract}
Abstrak: Tanggal 22 Juni 2018 terjadi bencana banjir bandang yang disebabkan oleh tanah longsor di kawasan lereng Gunung Raung di Kecamatan Songgon. Bencana ini menyebabkan ratusan orang mengungsi dan merusak 328 unit rumah. Adanya bencana tersebut, diperlukan analisis terhadap penyebab terjadinya tanah longsor serta melakukan pencegahan dan mitigasi dengan pemetaan potensi tanah longsor. Penelitian ini menggunakan metode analisis Sistem Informasi Geografis (SIG) dan pembobotan Analytical Hierarchy Process (AHP) dengan narasumber pegawai Badan Penanggulangan Bencana Daerah Kabupaten Banyuwangi dan Dosen Teknik Geofisika ITS. Parameter penyebab tanah longsor yang digunakan mengacu pada Permen PU No. 22/PRT/M/2007, parameter tersebut antara lain kemiringan lereng, kondisi tanah, batuan penyusun lereng, kondisi hidrologi, curah hujan, kerentanan gerakan tanah dan tutupan lahan. Hasil dari penelitian ini didapatkan bahwa dengan metode AHP, kerentanan gerakan tanah mempunyai pengaruh lebih besar terhadap tanah longsor dengan bobot sebesar 34\%, diikuti dengan parameter lain yaitu kemiringan lereng $17 \%$, jenis tanah $14 \%$, curah hujan $14 \%$, jenis batuan $12 \%$, kerapatan sungai $5 \%$ dan tutupan lahan $4 \%$. Selanjutnya, didapatkan tiga kelas potensi tanah longsor yaitu potensi rendah sebesar 9.527,09 Ha, potensi sedang sebesar 8.410,19 Ha dan potensi tinggi sebesar 3.283,23 Ha dengan daerah yang berpotensi tinggi terhadap potensi tanah longsor yaitu Desa Bayu dan Desa Sumberarum di Kecamatan Songgon.

Copyright () 2020 Geoid. All rights reserved.

Abstract: On June 22 2018, there was a flash flood disaster caused by landslides on the slopes of Mount Raung in Songgon Sub-District. This disaster caused hundreds of people to flee and damaged 328 housing units. The existence of this disaster requires an analysis of the causes of landslides as well as prevention and mitigation by mapping the potential for landslides. This research uses Geographical Information System (GIS) analysis method and weighting of Analytical Hierarchy Process (AHP) with the resource persons of the Banyuwangi Regional Disaster Management Agency and Geophysical Engineering lecturers-ITS. The parameters that cause landslides used refer to Permen PU No. 22 / PRT / M / 2007, these parameters include slope, soil conditions, rock making up slopes, hydrological conditions, rainfall, soil movement vulnerability and land cover. The results of this study found that with the AHP method, soil movement susceptibility has a greater effect on landslides with a weight of 34\%, followed by other parameters, namely 17\% slope, 14\% soil type, 14\% rainfall, 12\% rock type., 5\% river density and $4 \%$ land cover. Furthermore, three classes of landslide potential were obtained, namely low potential of 9,527.09 hectares, medium potential of 8,410.19 hectares and high potential of 3,283.23 hectares with areas that have high potential for landslides, namely Bayu Village and Sumberarum Village in Songgon Sub-District.
\end{abstract}

Kata kunci : Analytical Hierarchy Process; Sistem Informasi Geografis; Tanah Longsor

\section{Pendahuluan}

Permen PU Nomor 22/PRT/M/2007 mengatakan secara geografis sebagian besar wilayah Negara Kesatuan Republik Indonesia berada pada kawasan rawan bencana alam dan salah satu bencana alam yang sering terjadi adalah tanah longsor. Tanah longsor yaitu suatu proses perpindahan massa tanah atau batuan pembentuk lereng dengan arah miring dari kedudukan semula, sehingga terpisah dari massa yang mantap karena pengaruh gravitasi, dengan jenis gerakan berbentuk translasi dan/atau rotasi. 
Pada tanggal 22 Juni 2018 terjadi bencana banjir bandang yang disebabkan oleh longsor di kawasan lereng Gunung Raung di Kecamatan Songgon. Banjir bandang yang terjadi pada Jumat, 22 Juni 2018 bukanlah yang pertama, tercatat sepanjang tahun 2018 sedikitnya sudah tiga kali terjadi, namun pada tanggal tersebut adalah musibah yang paling parah. Menurut Pusat Vulkanologi, Mitigasi dan Bencana (PVMBG) Bandung menyatakan bencana longsor di Gunung Pendil ini disebabkan oleh peristiwa alam, dimana longsor ini terjadi akibat banyaknya pelapukan material vulkanik dan merupakan gunung api tua yang tumbuh di kaldera besar. Ketika curah hujan sangat tinggi terjadi selama empat hari, membuat air semakin susah masuk dan gravitasi air turun sehingga terjadi longsor dan menyebabkan banjir bandang.

Bencana tanah longsor yang terjadi di kawasan Kabupaten Banyuwangi ini sudah dikaji oleh Maulana (2019) untuk mengidentifikasi perubahan lingkungan fisik lahan daerah yang terdampak dengan menggunakan data penginderaan jauh satelit serta pembuatan peta potensi tanah longsor dengan menggunakan parameter fisik berupa curah hujan, kemiringan lereng, geologi, jenis tanah dan tutupan lahan. Akan tetapi pada penelitian tersebut, tidak mengkaji besarnya pengaruh terhadap faktor-faktor tanah longsor dikarenakan pembobotan yang digunakan mengacu pada Laporan Akhir Pengkajian Potensi Bencana Kekeringan, Banjir dan Longsor Berbasis Sistem Informasi Geografis oleh Pusat Penelitian dan Pengembangan Tanah dan Agroklimat. Sedangkan pada penelitian kali ini akan dilakukan analisis parameter penyebab tanah longsor dan potensi tanah longsor di Kecamatan Songgon, Kabupaten Banyuwangi dengan parameter yang digunakan mengacu pada Permen PU No. 22/PRT/M/2007 meliputi aspek fisik yaitu kemiringan lereng, curah hujan, kondisi hidrologi, dan tutupan lahan sedangkan untuk aspek geologi yaitu kondisi tanah, batuan penyusun lereng dan kerentanan gerakan tanah dengan menggunakan analisis spasial Sistem Informasi Geografis (SIG) dan pembobotan Analytical Hierarchy Process (AHP).

\section{Data dan Metode}

Penelitian ini dilakukan di Kecamatan Songgon, Kabupaten Banyuwangi yang terletak di antara koordinat $8^{\circ} 5^{\prime} 53,19^{\prime \prime}-8^{\circ} 16^{\prime} 22,09^{\prime \prime} \mathrm{LS}$ dan $114^{\circ} 9^{\prime} 51^{\prime \prime}-114^{\circ} 15^{\prime} 3,14^{\prime \prime}$ BT yang ditunjukkan pada Gambar 1 . Dengan data utama yang digunakan yaitu Citra Sentinel-2A Tahun 2019, data curah hujan tahun 2018 yang didapatkan dari BMKG, DEM SRTM, data spasial sungai, Daerah Aliran Sungai (DAS), jenis tanah, geologi dan kerentanan gerakan tanah yang didapatkan dari BAPPEDA Kabupaten Banyuwangi. Sedangkan untuk pembobotan Analytical Hierarchy Process (AHP), narasumber yang digunakan yaitu pegawai Badan Penanggulangan Bencana Daerah (BPBD) Banyuwangi dan Dosen Teknik Geofisika ITS.

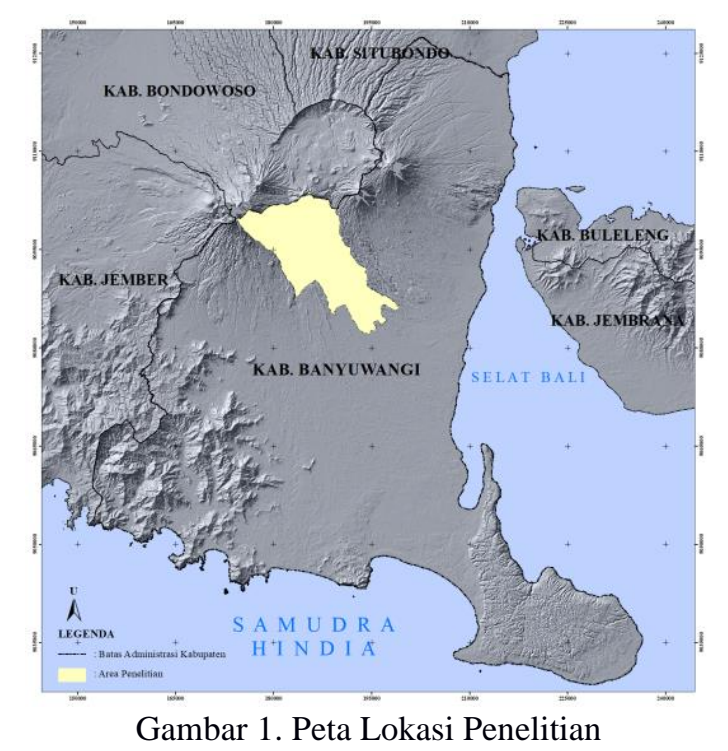

Metode yang digunakan pada penelitian ini meliputi Analytical Hierarchy Process (AHP) untuk mendapatkan nilai bobot yang didapatkan dari narasumber, Maximum Likelihood Classification untuk 
membuat peta tutupan lahan tahun 2019 yang diklasifikasikan menjadi badan air, pemukiman, hutan dan perkebunan, semak belukar serta sawah dan tegalan, pembuatan slope dari data DEM SRTM untuk membuat peta kelerengan tanah, interpolasi spasial metode Inverse Distance Weighted (IDW) untuk membuat peta isohyet curah hujan pada musim basah, perhitungan kerapatan sungai dari data spasial sungai dan Daerah Aliran Sungai (DAS) dengan rumus sebagai berikut.

$D d=\frac{\sum L n}{A}$

Keterangan:

Dd $\quad=$ kerapatan aliran $\left(\mathrm{km} / \mathrm{km}^{2}\right)$

Ln = panjang sungai $(\mathrm{km})$

A $\quad=$ luas DAS $\left(\mathrm{km}^{2}\right)$

Metode skoring digunakan untuk pemberian nomor ranking pada ketujuh parameter, meliputi data spasial jenis tanah, geologi, kerentanan gerakan tanah, tutupan lahan, kelerengan tanah, curah hujan dan kerapatan sungai dengan tabel skoring ditunjukkan pada Tabel 1.

Tabel 1 Skoring Tiap Parameter

\begin{tabular}{|c|c|c|c|}
\hline Parameter & Kelas & Skor & Deskripsi \\
\hline \multirow{5}{*}{ Tutupan Lahan } & Badan Air & 1 & Tidak Peka \\
\hline & Pemukiman & 2 & Kurang Peka \\
\hline & Hutan dan Perkebunan & 3 & Agak Peka \\
\hline & Semak Belukar & 4 & Peka \\
\hline & Tegalan, Sawah & 5 & Sangat Peka \\
\hline \multirow{5}{*}{ Kemiringan Lereng } & $0-8 \%$ & 1 & Datar \\
\hline & $8-15 \%$ & 2 & Landai \\
\hline & $15-25 \%$ & 3 & Agak Curam \\
\hline & $25-45 \%$ & 4 & Curam \\
\hline & $>45 \%$ & 5 & Sangat Curam \\
\hline \multirow{5}{*}{$\begin{array}{l}\text { Curah Hujan } \\
\quad(\mathrm{mm})\end{array}$} & $<200$ & 1 & Sangat kering \\
\hline & $201-300$ & 2 & Kering \\
\hline & $301-400$ & 3 & Sedang \\
\hline & $401-500$ & 4 & Basah \\
\hline & $>500$ & 5 & Sangat Basah \\
\hline \multirow{5}{*}{$\begin{array}{l}\text { Kerapatan Sungai } \\
\qquad\left(\mathrm{km} / \mathrm{km}^{2}\right)\end{array}$} & $>3,10$ & 1 & Kekeringan \\
\hline & $2,28-3,10$ & 2 & Agak Kering \\
\hline & $1,45-2,27$ & 3 & Sedang \\
\hline & $0,62-1,44$ & 4 & $\begin{array}{c}\text { Agak } \\
\text { Menggenang }\end{array}$ \\
\hline & $<0,62$ & 5 & Menggenang \\
\hline \multirow{5}{*}{$\begin{array}{c}\text { Kerentanan Gerakan } \\
\text { Tanah }\end{array}$} & Zona V & 1 & Aman \\
\hline & Zona IV & 2 & Sangat Rendah \\
\hline & Zona III & 3 & Rendah \\
\hline & Zona II & 4 & Sedang \\
\hline & Zona I & 5 & Tinggi \\
\hline \multirow{5}{*}{ Jenis Tanah } & Aluvial, Glei & 1 & Tidak Peka \\
\hline & Latosol & 2 & Sedikit Peka \\
\hline & Brown forest, Mediteran & 3 & Agak Peka \\
\hline & Andosol, Grumosol, Podsol & 4 & Peka \\
\hline & Regosol, Litosol, Organosol & 5 & Sangat Peka \\
\hline \multirow{2}{*}{ Geologi } & Dataran Aluvial & 1 & Tidak Peka \\
\hline & Perbukitan Kapur & 2 & Sedikit Peka \\
\hline
\end{tabular}




\begin{tabular}{clc}
\hline Perbukitan Granit & 3 & Agak Peka \\
\hline Perbukitan Batuan Sedimen & 4 & Peka \\
\hline Bukit Basal Clay-Shale & 5 & Sangat Peka \\
\hline
\end{tabular}

Setelah itu, ketujuh parameter tersebut dilakukan proses overlay dengan metode intersect untuk mendapatkan potensi tanah longsor. Dari hasil overlay tersebut, lalu dihitung skor total dengan menggunakan persamaan (2) yaitu sebagai berikut.

$S_{T}=B_{1}\left(S_{1}\right)+B_{2}\left(S_{2}\right)+\cdots+B_{n}\left(S_{n}\right)$

Keterangan:

$S_{T} \quad=$ Skor total

$B_{1}, B_{2}, \ldots, B_{n}=$ Bobot tiap parameter

$S_{1}, S_{2}, \ldots, S_{n} \quad=$ Skor tiap parameter

$n \quad=$ Jumlah parameter

Hasil skor total tersebut diklasifikasikan menjadi tiga kelas potensi sesuai dengan pedoman Badan Nasional Penanggulangan Bencana (BNPB) yaitu potensi rendah, sedang dan tinggi. Persamaan rentang kelas klasifikasi ditunjukkan dengan persamaan (3).

$K_{i}=\frac{\text { Skor tertinggi-Skor terendah }}{\text { jumlah kelas yang diinginkan }}$

\section{Hasil dan Pembahasan}

Hasil pengolahan pembobotan Analytical Hierarchy Process (AHP) yang didapatkan dari narasumber, menghasilkan bahwa aspek geologi mempunyai pengaruh yang lebih besar terhadap potensi tanah longsor dengan bobot $60 \%$ daripada aspek fisik. Sedangkan untuk parameternya, menunjukkan bahwa parameter kerentanan gerakan tanah mempunyai pengaruh yang lebih besar dari parameter yang lain dengan bobot $34 \%$, hasil nilai bobot parameter yang lain bisa dilihat pada Tabel 2.

Tabel 2 Hasil Bobot Parameter Metode Analytical Hierarchy Process

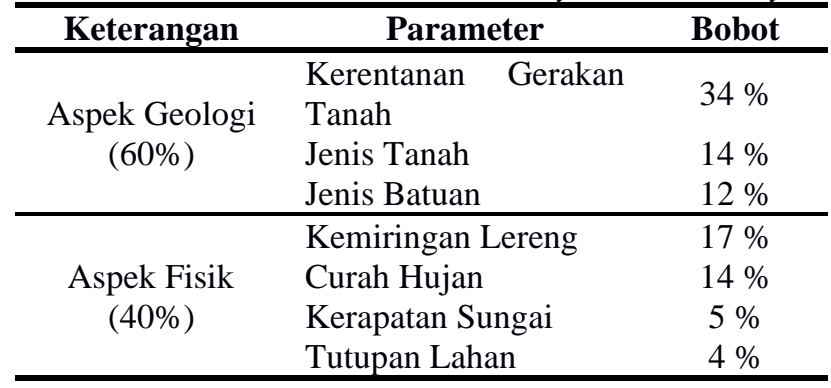

Proses skoring yang dilakukan pada ketujuh parameter dihasilkan bahwa dari aspek fisik yaitu tutupan lahan di Kecamatan Songgon didominasi oleh hutan dan perkebunan dengan luas sebesar 15.189,46 Ha dan sebagian kecil dimiliki oleh kelas badan air dengan luas 108,3 Ha. Menurut ESDM (2006), tanah longsor banyak terjadi di daerah tata lahan persawahan, perladangan dan adanya genangan air di lereng yang terjal. Sedangkan untuk sawah dan tegalan di Kecamatan Songgon, menghasilkan luas sebesar 4.261,12 Ha. Untuk hasil kelerengan tanah didominasi oleh kelerengan landai $(8-15 \%)$ dengan luas 8.661,55 Ha, untuk kelas sangat curam (>45\%) yang berwarna merah pada Gambar 2(b) hanya dimiliki oleh Desa Bayu dan Desa Sumberarum dengan luas 375,22 Ha. Hasil interpolasi curah hujan dengan metode IDW didapatkan bahwa seluruh Kecamatan Songgon memiliki kondisi sangat basah dengan curah hujan sebesar $>500 \mathrm{~mm}$. Untuk kerapatan sungai di Kecamatan Songgon hanya memiliki kerapatan sungai sedang $\left(1,45-2,27 \mathrm{~km} / \mathrm{km}^{2}\right)$ dengan luas $18.429,13 \mathrm{Ha}$ dan kerapatan sungai agak kering $\left(2,28-3,10 \mathrm{~km} / \mathrm{km}^{2}\right)$ dengan luas 2.791,38 Ha. Kerapatan sungai menggambarkan kapasitas penyimpanan air permukaan dalam cekungan-cekungan seperti 
danau, rawa dan badan sungai yang mengalir di suatu Daerah Aliran Sungai. Hubungan antara kerapatan sungai dengan tanah longsor terletak pada permeabilitas batuan dalam meloloskan air (Nurwidyanto dkk 2006). Struktur batuan dengan pori-pori yang kecil memiliki nilai kerapatan yang kecil. Hal ini terjadi karena air yang turun akan tertahan oleh batuan dengan pori-pori kecil sehingga tingkat erosi menjadi lebih besar.

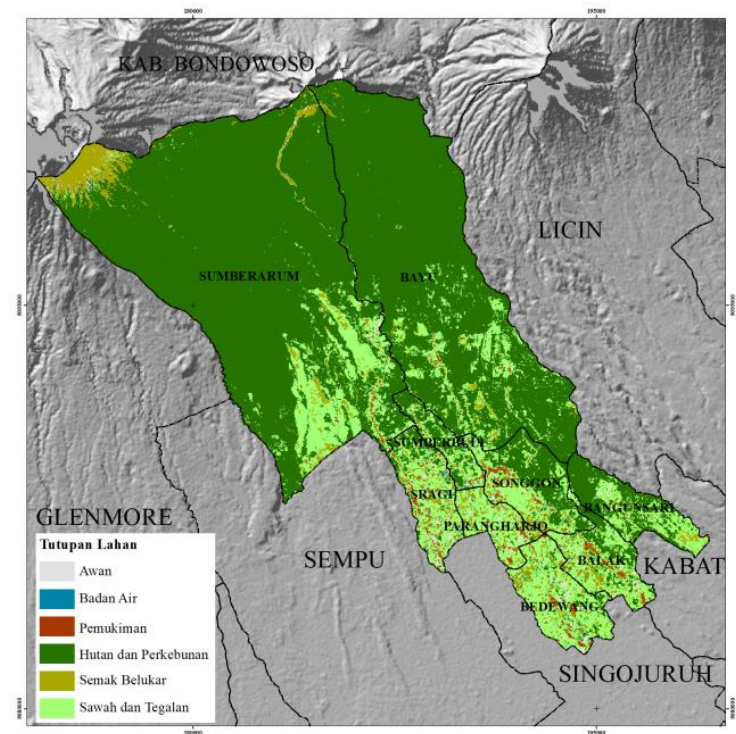

(a)

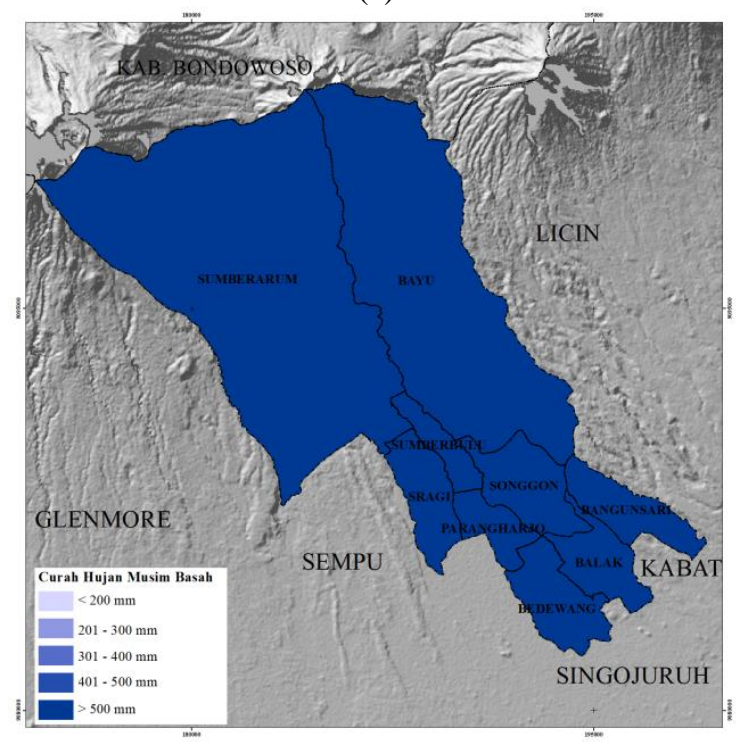

(c)

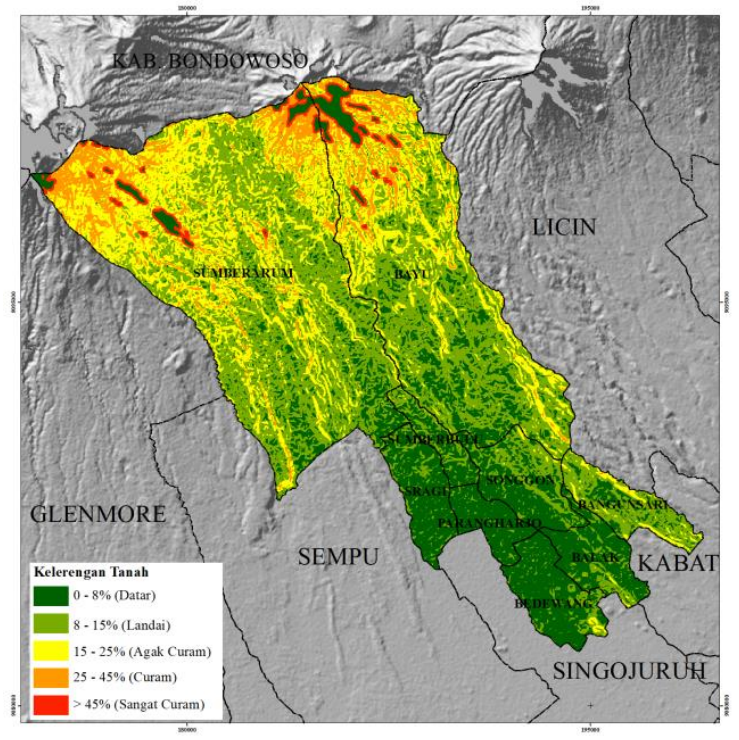

(b)

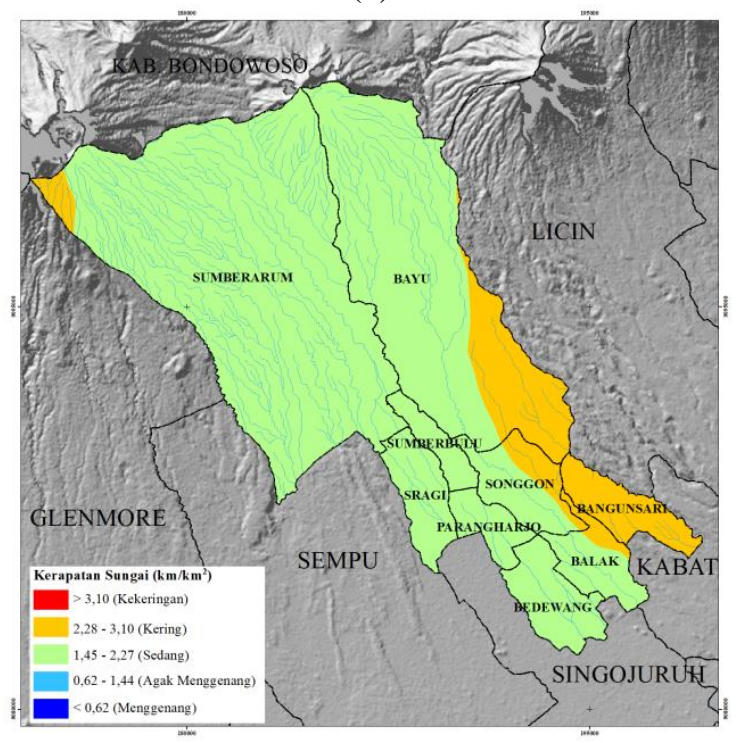

(d)

Gambar 2 Peta Parameter Aspek Fisik (a) Tutupan Lahan (b) Kelerengan Tanah (c) Curah Hujan dan (d) Kerapatan Sungai

Sedangkan, untuk parameter aspek geologi yaitu jenis tanah yang ditunjukkan pada Gambar 3 (a), di Kecamatan Songgon memiliki jenis tanah regosol, litosol, organosol sebesar 14.307,04 Ha, jenis tanah andosol, grumosol, podsol seluas 5.787,46 Ha dan jenis tanah latosol sebesar 1.126,01 Ha. Selanjutnya, parameter jenis batuan, jenis batuan merupakan salah satu gaya pendorong terjadinya longsor. Batuan yang tidak kuat seperti batuan sedimen yang berukuran pasir dan juga clay shale yang berukuran lempung, umumnya rentan terhadap tanah longsor. Pada penelitian ini, di Kecamatan Songgon memiliki jenis batuan dataran aluvial seluas 9.341,62 Ha, jenis batuan perbukitan granit sebesar 8.102,51 Ha dan perbukitan batuan sedimen sebesar 3.776,38 Ha. Parameter aspek geologi yang terakhir yaitu kerentanan gerakan tanah, tanah longsor bisa terjadi karena adanya gerakan tanah, dimana gerakan tanah mencakup gerakan rayapan dan aliran maupun longsoran. Dilihat pada Gambar 3 (c), bahwa Kecamatan Songgon memiliki kerentanan tinggi 
(Zona I) sebesar 570,79 Ha, kerentanan sedang (Zona II) sebesar 8.214,22 Ha, kerentanan sangat rendah (Zona IV) sebesar 7.624,36 Ha, zona aman (zona V) sebesar 4.811,14 Ha.

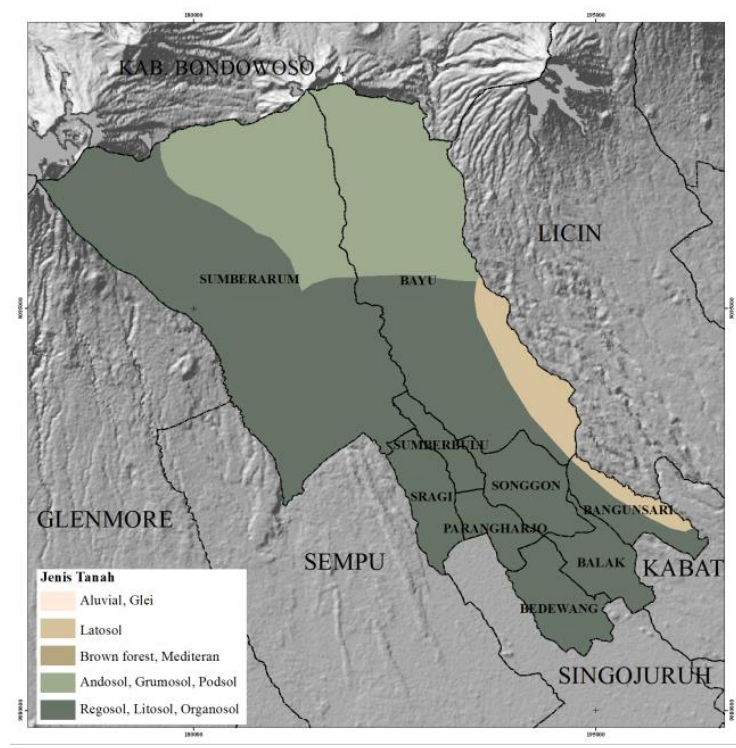

(a)

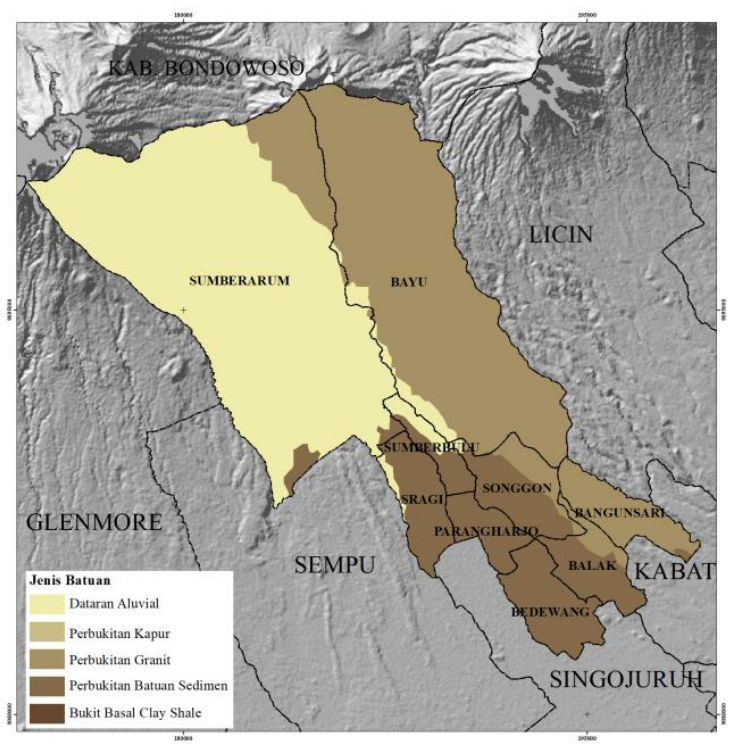

(b)

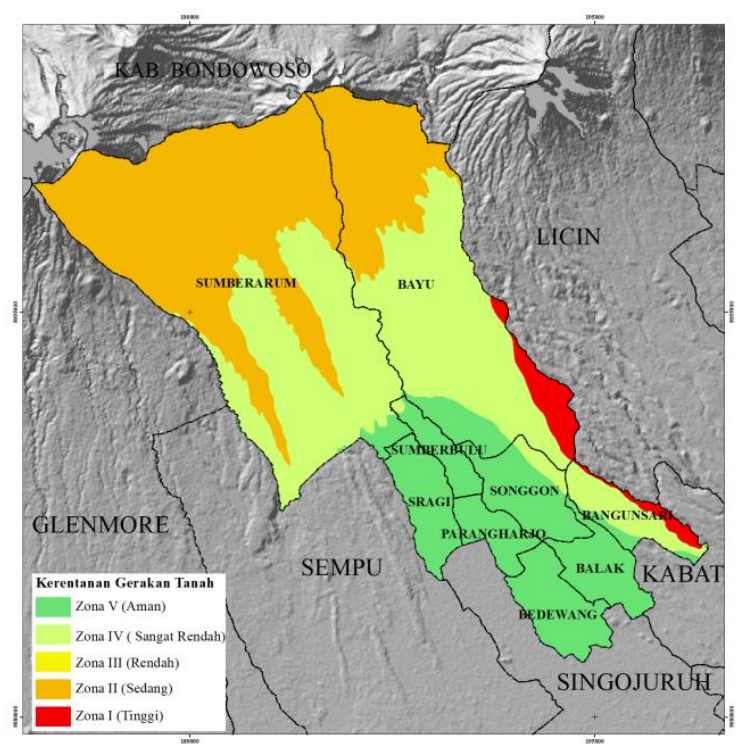

(c)

Gambar 3 Peta Parameter Aspek Geologi (a) Jenis Tanah (b) Geologi dan (c) Kerentanan Gerakan Tanah

Hasil dari overlay ketujuh parameter dengan metode intersect menghasilkan Peta Potensi Tanah Longsor dengan tiga tingkat potensi, yaitu potensi sedang, rendah dan potensi tinggi. Hasil dari Peta Potensi Tanah Longsor ditunjukkan pada Gambar 4 dengan hasil perhitungan interval klasifikasi ditunjukkan pada Tabel 3.

Tabel 3 Klasifikasi Potensi Tanah Longsor

\begin{tabular}{cc}
\hline Interval & Tingkat Potensi \\
\hline $2,18-2,93$ & Rendah \\
$2,94-3,69$ & Sedang \\
$3,70-4,45$ & Tinggi \\
\hline
\end{tabular}




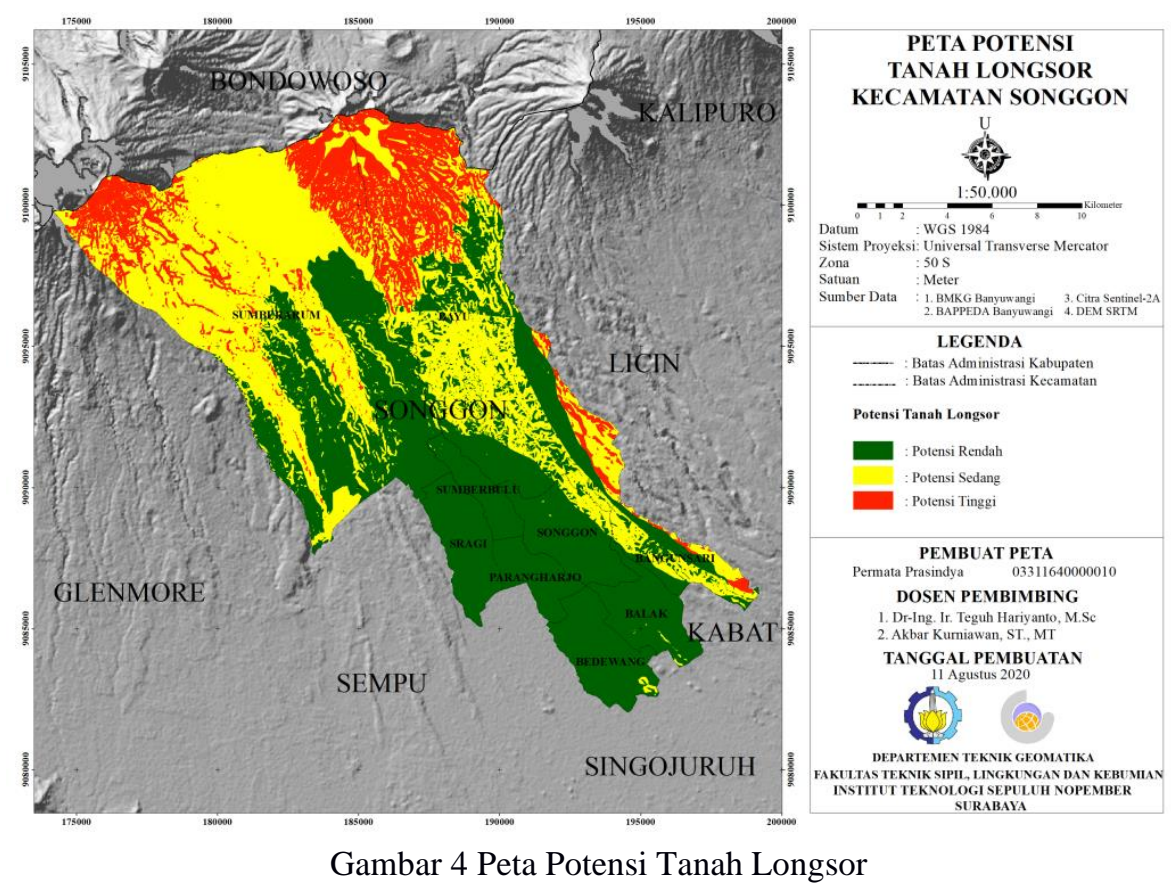

Berdasarkan hasil peta tersebut, dapat dilihat bahwa tingkat potensi tinggi ditunjukkan dengan warna merah, tingkat potensi sedang dengan warna kuning dan tingkat potensi rendah dengan warna hijau. Hasil pengolahan Peta Potensi Tanah Longsor di Kecamatan Songgon pada Gambar 4, didominasi oleh tingkat potensi rendah dengan luas sebesar 9.527,09 $\mathrm{Ha}$ atau 44,09\%, tingkat potensi sedang dengan luas sebesar 8.410,19 $\mathrm{Ha}$ atau 39,63\% serta tingkat potensi tinggi dengan luas area sebesar 3.283,23 Ha atau 15,47\%. Berikut adalah luas tingkat potensi tanah longsor tiap desa di Kecamatan Songgon.

Tabel 4 Luas Tingkat Potensi Tanah Longsor Tiap Desa di Kecamatan Songgon

\begin{tabular}{|c|c|c|c|}
\hline Desa & $\begin{array}{l}\text { Tingkat } \\
\text { Potensi }\end{array}$ & $\begin{array}{l}\text { Luas } \\
\text { (Ha) }\end{array}$ & $\begin{array}{l}\text { Total } \\
\text { Luas } \\
\text { (Ha) }\end{array}$ \\
\hline \multirow{3}{*}{ Balak } & Rendah & 732,88 & \multirow{3}{*}{740,83} \\
\hline & Sedang & 7,95 & \\
\hline & Tinggi & 0,00 & \\
\hline \multirow{3}{*}{ Bangunsari } & Rendah & 356,31 & \multirow{3}{*}{787,22} \\
\hline & Sedang & 382,37 & \\
\hline & Tinggi & 48,54 & \\
\hline \multirow{3}{*}{ Bayu } & Rendah & $1.946,17$ & \multirow{3}{*}{$6,281,21$} \\
\hline & Sedang & $2.712,72$ & \\
\hline & Tinggi & $1.622,32$ & \\
\hline \multirow{3}{*}{ Badewang } & Rendah & 881,54 & \multirow{3}{*}{897,42} \\
\hline & Sedang & 15,88 & \\
\hline & Tinggi & 0,00 & \\
\hline \multirow{3}{*}{ Parangharjo } & Rendah & 478,82 & \multirow{3}{*}{478,82} \\
\hline & Sedang & 0,00 & \\
\hline & Tinggi & 0,00 & \\
\hline \multirow{3}{*}{ Balak } & Rendah & 732,88 & \multirow{3}{*}{740,83} \\
\hline & Sedang & 7,95 & \\
\hline & Tinggi & 0,00 & \\
\hline \multirow{3}{*}{ Bangunsari } & Rendah & 356,31 & \multirow{3}{*}{787,22} \\
\hline & Sedang & 382,37 & \\
\hline & Tinggi & 48,54 & \\
\hline Bayu & Rendah & $1.946,17$ & $6,281,21$ \\
\hline
\end{tabular}




\begin{tabular}{|c|c|c|c|}
\hline & $\begin{array}{c}\text { Sedang } \\
\text { Tinggi }\end{array}$ & $\begin{array}{l}2.712,72 \\
1.622,32 \\
\end{array}$ & \\
\hline \multirow{3}{*}{ Badewang } & Rendah & 881,54 & \multirow{3}{*}{897,42} \\
\hline & Sedang & 15,88 & \\
\hline & Tinggi & 0,00 & \\
\hline \multirow{3}{*}{ Parangharjo } & Rendah & 478,82 & \multirow{3}{*}{478,82} \\
\hline & Sedang & 0,00 & \\
\hline & Tinggi & 0,00 & \\
\hline \multirow{3}{*}{ Songgon } & Rendah & 867,04 & \multirow{3}{*}{971,08} \\
\hline & Sedang & 104,04 & \\
\hline & Tinggi & 0,00 & \\
\hline \multirow{3}{*}{ Sragi } & Rendah & 796,71 & \multirow{3}{*}{796,71} \\
\hline & Sedang & 0,00 & \\
\hline & Tinggi & 0,00 & \\
\hline \multirow{3}{*}{ Sumberarum } & Rendah & $3.063,47$ & \multirow{3}{*}{$9.862,29$} \\
\hline & Sedang & $5.186,45$ & \\
\hline & Tinggi & $1.612,37$ & \\
\hline \multirow{3}{*}{ Sumberbulu } & Rendah & 404,15 & \multirow{3}{*}{404,93} \\
\hline & Sedang & 0,78 & \\
\hline & Tinggi & 0,00 & \\
\hline Total (Ha) & & & $21.220,51$ \\
\hline
\end{tabular}

Dilihat dari Tabel 4, didapatkan bahwa Desa Bayu dan Desa Sumberarum mendominasi tingkat potensi tingi. Hasil tersebut dibuktikan dengan adanya kejadian bencana tanah longsor pada tanggal 22 Juni 2018 yang terjadi di kawasan Gunung Raung, tepatnya di Bukit Pendil, Desa Sumberarum. Titik Puncak tanah longsor bisa dilihat pada Gambar 5.

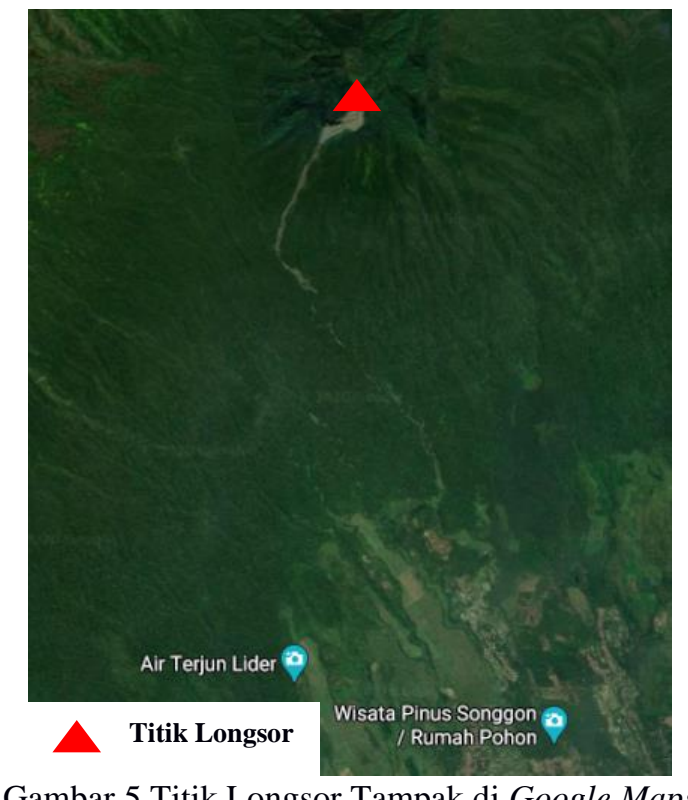

Sedangkan untuk kejadian tanah longsor di Desa Bayu terjadi pada tanggal 4 Februari 2018 tepatnya di Dusun Sambungreji RT 02 RW 03. Kejadian ini mengakibatkan dua korban meninggal akibat tertimbun longsor dan satu selamat (Memontum.com 2018). Suasana kejadian tanah longsor tersebut bisa dilihat pada Gambar 6. 


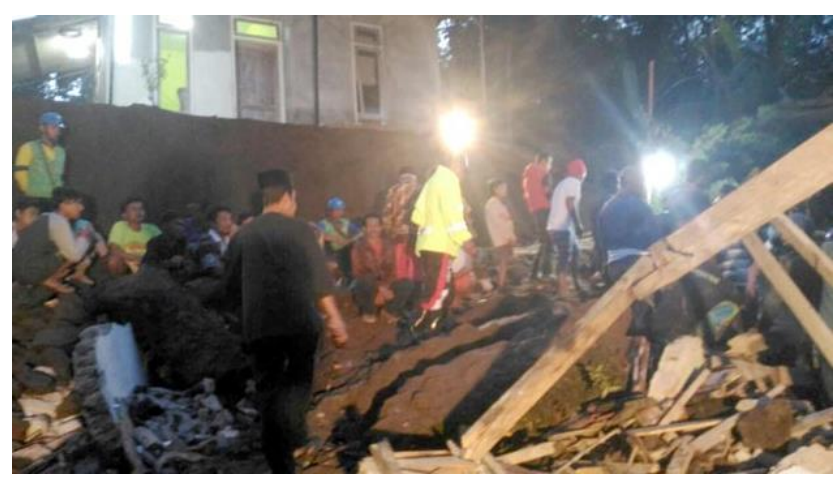

Gambar 6 Kejadian Tanah Longsor di Dusun Sambungreji, Desa Bayu (sumber: Memontum.com 2018)

\section{Kesimpulan}

Kesimpulan yang dapat diambil dari penelitian ini yaitu bahwa dari ketujuh parameter yang mengacu pada Permen PU. No. 22/PRT/M/2007, parameter kerentanan gerakan tanah mempunyai pengaruh yang besar terhadap potensi tanah longsor dengan bobot sebesar 34\%. Hasil ini didapat dari perhitungan metode Analytical Hierarchy Process (AHP) dengan nilai yang didapat berasal dari narasumber, yaitu pegawai Badan Penanggulangan Bencana Daerah (BPBD) Banyuwangi dan Dosen Teknik Geofisika-ITS. Sedangkan, untuk hasil akhir dari penelitian ini yaitu Peta Potensi Tanah Longsor didapatkan tiga kelas potensi sesuai dengan pedoman Badan Nasional Penanggulangan Bencana (BNPB) yaitu potensi rendah, sedang dan tinggi. Masing-masing tingkat potensi mempunyai luas sebesar 9.527,09 Ha untuk potensi rendah, 8.410,19 Ha untuk potensi sedang dan 3.283,23 Ha untuk potensi tinggi. Potensi tinggi di Kecamatan Songgon didominasi oleh Desa Bayu dan Desa Sumberarum yang dibuktikan dengan adanya kejadian tanggal 22 Juni 2018 di kawasan Gunung Raung, Bukit Pendil, Desa Sumberarum dan tanggal 4 Februari 2018 di Dusun Sambungreji, Desa Bayu.

\section{Ucapan Terimakasih}

Penulis mengucapkan terimakasih kepada Badan Perencanaan Pembangunan Daerah (BAPPEDA) Banyuwangi yang telah memberikan data spasial yang digunakan penelitian kali ini. Pegawai Badan Penanggulangan Bencana Daerah (BPBD) Banyuwangi dan Bapak Amien selaku Dosen Teknik GeofisikaITS yang sudah menyempatkan waktunya sebagai responden dalam penelitian ini.

\section{Daftar Pustaka}

ESDM. (2006). Pengenalan Gerakan Tanah. https://www.esdm.go.id/assets/media/content/Pengenalan_Gerakan_Tan ah.pdf diakses tanggal 11 Agustus 2020.

Maulana, Muhammad Ridho. (2019).Analisa Perubahan Lingkungan Fisik Lahan Akibat Bencana Tanah Longsor Menggunakan Citra Satelit Sentinel (Studi Kasus: Tanah Longsor di Kabupaten Banyuwangi)Skripsi.Fakultas Teknik Sipil, Lingkungan dan Kebumian, Institut Teknologi Sepuluh Nopember, Surabaya

Memontum.com. (2018). Dusun Bayu Longsor, 2 Tewas. https://memontum.com/24358-dusun-bayu-longsor-2-tewas diakses tanggal 11 Agustus 2020.

Nurwidyanto, M. Irham, Yustiana, Meida, dan Widada, Sugeng.(2006). Pengaruh Ukuran Butir Terhadap Porositas Dan Permeabilitas Pada Batupasir.Jurnal Fisika Teori, Eksperimen dan Fisika Aplikasi, Oktober 2006, vol. 9 (4), 191 - 195.

Peraturan Menteri Pekerjaan Umum Nomor 22/PRT/M/2007 Tentang Pedoman Penataan ruang Kawasan Rawan Bencana Tanah Longsor 